\title{
Perceptions of the History Department Students About the Distance Education Courses
}

\author{
Sezai Öztaş \\ Correspondence: Sezai Öztaş, Kırklareli University, Faculty of Arts and Science, Department of History, Turkey.
}

Received: February 5, 2018

Accepted: February 23, 2018

Online Published: February 27, 2018

doi:10.11114/jets.v6i3.2993

URL: https://doi.org/10.11114/jets.v6i3.2993

\begin{abstract}
The aim of this research is to determine the perceptions of the students in the history department who take the courses of Atatürk's Principles and History of Revolution (APHR), Turkish Language (TL) and Basic Information Technologies (BIT) in distance education. In this research, the questionnaires, which were used as data collection tool, were applied to 123 students at Kırklareli University during the spring term of 2016-2017 academic year and who took APHR, TL and BIT courses in distance education. IBM SPSS Statistics 20 has been used to analyze the collected data. Descriptive statistics of the collected data were given in detail. It was found that attitude scores toward teaching APHR, TL and BIT courses with distance education were statistically differed based on "gender" and "existence of internet connectivity which can be used consistently" after performing independent samples t-test and One-Way ANOVA. There was no statistically significant association found between "course type (APHR/TL/BIT)" and "students' behavior of spending time with other things during these courses" after performing Chi-Square Test of Independence. However, there was found statistically significant association between "course type" and "the students' perceptions about the impact of attending these courses as distance education on achieving learning outcomes", and between "course type" and "students' perceptions about the convenience of teaching these courses as distance education" after performing Chi-Square Test of Independence $(p<0.05)$.
\end{abstract}

Keywords: Atatürk's principles and history of revolution education, Turkish language education, basic information technologies education, distance education, students' perceptions

\section{Introduction}

Information and communication technologies are rapidly developing. As a consequence of this, their integration into the education environments is clearly seen. The number of universities offering distance education courses has been increasing in both Turkey and other countries recently. Basically, distance education is the system in which the teacher and the student are in separate environments. Distance education term contains several terms such as "home study", "independent study", "distance teaching or teaching at a distance", "distance education" (Keegan, 1990). Distance education is defined as "institution-based, formal education where the learning group is separated, and where interactive telecommunications systems are used to connect learners, resources, and instructors." (Schlosser \& Simonson, 2009). According to Moore \& Kearsley (2012) "distance education is teaching and planned learning in which teaching normally occurs in a different place from learning, requiring communication through technologies as well as special institutional organization."

As an answer to the question: "Why Distance Education?", Moore \& Kearsley (2012) gives the following justifications:

- increasing access to learning and training as a matter of equity

- providing opportunities for updating skills of the workforce

- improving the cost effectiveness of educational resources

- improving the quality of existing educational structures

- enhancing the capacity of the educational system

- balancing inequalities between age groups

- delivering educational campaigns to specific target audiences

- providing emergency training for key target groups 
- expanding the capacity for education in new subject areas

- offering combination of education with work and family life

- adding an international dimension to the educational experience

Distance education term firstly takes place in the University of Wisconsin' catalogue for the year 1892, and again it was first used in an article written in 1906 by William Lighty, the director of the same university (Verduin \& Clark, 1994).

Distance education, which was put forward as a concept in as far back as 1700s, has been practiced since those years. In the Boston Newspaper dated March 20, 1728, it was announced that "stenography courses" would be given via letters. In a Swedish newspaper dated 1833, there was an advertisement to give written expression courses via letters. Yet, mutual communication and grading were not mentioned in either of these two advertisements. It is not known if distance education was exercised, since there is no clear evidence regarding whether the hypothetical courses offered in these two advertisements were given or not, whether there was a two-way communication between the student and the teacher, and if the courses were given, whether they were graded or not. It is acknowledged that the first distance education practice in the world was initiated by Isaac Pitman in England in 1840. Pitman, a stenographer, began teaching stenography via letters. Distance education department was opened at the University of Chicago in the United States in 1892 (Kaya, 2002). It is seen that distance education began to be implemented in many countries in the following years.

The first distance education studies in Turkey were brought to agenda with "teacher education report" presented by J. Dewey in 1924, settled as a concept in 1927 and studies on the subject accelerated after 1950. The first distance education activities in the Turkish Education System started with the application of teaching via letters in 1950. In 1960, the Ministry of National Education, Undersecretariat of Vocational and Technical Educationestablished the Central Board of Teaching via Letters within the body of Statistics and Publication Directorate. Turkish Radio and Television Corporation (TRT), which started broadcasting in 1968, featured in educational telecasts. Education-relevant programmes, prepared by the Ministry of National Education, Film Radio Television Education Centre (FRTEM), were broadcast in the same year. In 1973, FRTEM went on to broadcast various courses and programmes for primary school, elementary school and high school with the name of school television (İşman, 2011). In 1975, the Common Higher Education Institution (YAYKUR) was established and planned to implement a multi-instrumental education by putting the television in the center (Özdil, 1986). Open Education Faculty was founded within Anadolu University in 1982 (Demiray, 1994). Open High School was opened in 1992 and Open Primary School in 1998.

Today, distance education in Turkey, as in all levels of education, began to spread in higher education, and several universities began to offer some courses via distance education. The lack of physical structure, academic staff, the problems experienced in sending academic staff to the units outside the center and some other inadequacies in the universities brought up the option of giving some courses in formal education via distance education (Öztaş \& Kılıç, 2017).

The program of the Department of History within Kurklareli University, the Faculty of Art and Science, where the research was conducted, is a formal program. Only APHR, TL and BIT courses in this formal program are conducted in distance education. The distance education courses in this program can be followed both asynchronously and synchronously by the students. In addition, live courses are held through virtual classes. With the virtual classes, the instructors and the students can meet in the virtual platform synchronously. Students can track these virtual classroom records on the web at anytime and anywhere. In addition to being able to watch courses asynchronously and attend to synchronous lectures, students are able to correspond and communicate with the instructor responsible for the course asynchronously through the system. Besides students can meet with the instructor responsible for the course in person at times determined by the instructor. The midterm, final and make-up exams of these courses are conducted in the classroom environment on a day during the exam week specified in the academic calendar. Some studies have been made with regard to offering APHR, TL, BIT courses in the higher education institutions' curriculum via distance education (Barış, 2015; Doğan \& Tatık, 2015; Türkoğlu, 2015). However, no research has been found in the literature about the perceptions of the students in the history department only with regard to giving these three courses in distance education. It is important to investigate the perceptions of students who take these courses in distance education in terms of providing insight on exhibiting the strengths and weaknesses of offering these courses in distance education within the formal education programs and in terms of making these courses more effective. The aim of this study is to determine the perceptions of the students in the history department who take APHR, TL and BIT courses in distance education about taking these courses in distance education. With this aim in mind, answers to the following questions have been sought:

- Do the students who attended APHR, TL and BIT distance education courses have any information on distance education? 
- What are the perceptions of the students who attended APHR, TL and BIT courses in distance education about the convenience of these courses for distance education?

- What is the students' attitude of spending time with other things during the course who attended APHR, TL and BIT distance education courses?

- What are the students' perceptions about the impact of attending APHR, TL and BIT courses as distance education on achieving learning outcomes?

- What are the attitude scores of students who attended APHR, TL and BIT distance education courses toward teaching these courses with distance education?

- Is there any statistically significant difference by "gender" on attitude scores of students toward teaching APHR, TL and BIT courses with distance education who attend these courses as distance education?

- Are there any statistically significant differences by "existence of internet connectivity which can be used consistently" on attitude scores of students' toward teaching APHR, TL and BIT courses with distance education who attend to these courses as distance education?

- Is there an association between "course type (APHR/TL/BIT)" and "the students' perceptions about the impact of attending these courses as distance education on achieving learning outcomes"?

- Is there an association between "course type (APHR/TL/BIT)" and "students' perceptions about the convenience of teaching these courses as distance education"?

- Is there an association between "course type (APHR/TL/BIT)" and "students' behavior of spending time with other things during these courses"?

\section{Method}

\subsection{Research Model}

In this research descriptive survey model has been used. Descriptive model is the research approach in which the situation in the past or at present is defined as it is or it was (Karasar, 2012). Büyüköztürk et al. (2010) define the descriptive survey model as a type of research used for its convenience for the purpose of the research, for its usefulness in providing insight to participants' perceptions about a subject or an event, allowing to study on large samples, and presenting an existing situation.

\subsection{Study Group}

The population consists of 138 History Department students of Kurklareli University Faculty Of Arts And Science during the spring term of 2016-2017 academic year who have been attending APHR, TL and BIT courses as distance education. Since it was so hard to get all these students, convenience sampling method was used. During the implementation of this method, it was reached to 123 students who were available on the days when the survey was applied by convenience sampling method.

\subsection{Data Collection Tools}

The questionnaire which was used as a data collection tool was designed by researcher. This questionnaire consists of two parts. Some of the questions related to socio-demographic characteristics and distance education knowledge of respondents which constitute the first part of the questionnaire have been prepared benefiting from the studies conducted by Parlak (2007), Yalman \& Kutluca (2013), and Türkoğlu (2015); and the second part of the questionnaire have been prepared by the researcher through literature review. The second part contains questions aims to measure attitude levels of students' toward teaching APHR, TL and BIT courses with distance education who are attending these courses as distance education. In this part, studies conducted by Eygü \& Karaman (2013), Doğan \& Tatık (2015), and "Attitude Scale Towards Distance Education (ASTDE)" developed by Kışla (2005) were used. This part consists of 21 questions which were thought to measure different attitudes toward teaching APHR, TL and BIT courses with distance education. Responses for all students was taken with 5-point Likert-type scale (“(1) Strongly Disagree”, “(2) Disagree”, “(3) Undecided”, “(4) Agree” ve “(5) Strongly Agree”). As a consequence of this, the attitude scores (means) of students' toward teaching APHR, TL and BIT courses take value between 1 to 5, calculated individually for each of these courses. Scores close to 5 indicates "positive attitude", inversely scores close to 1 indicates "negative attitude" for attitude level of students' toward teaching APHR, TL and BIT courses with distance education.

\subsection{Data Analysis}

In order to analyze the data, IBM SPSS Statistics 20 Program was used. Descriptive statistics of the collected data was calculated. The attitude scores of students' toward teaching APHR, TL and BIT courses with distance education who are attending these courses as distance education were calculated by using students' responses for the second part of the 
questionnaire. Independent samples t-test performed whether there was a statistically significant difference or not on attitude scores of students' toward teaching APHR, TL and BIT courses with distance education who are attending these courses as distance education by "gender". One-Way ANOVA performed whether there was a statistically significant difference or not on attitude scores of students' toward teaching APHR, TL and BIT courses with distance education who are attending these courses as distance education by "existence of internet connectivity which can be used consistently". Additionally, Chi-Square Test of Independence performed whether there was an association between course type (APHR/TL/ BIT) and students' behavior of spending time with other things during these courses. Also, Chi-Square Test of Independence performed whether there was an association between "course type" and "the students' perceptions about the impact of attending these courses as distance education on achieving learning outcomes", and between "course type" and "students' perceptions about the convenience of teaching these courses as distance education". All these statistical tests performed at the $95 \%$ confidence level.

\section{Results}

In this section, the results of data analyzes were given in the tables.

Table 1. Distribution of students by gender

\begin{tabular}{lll}
\hline Gender & Frequency & Percent \\
\hline Female & 64 & 52 \\
Male & 59 & 48 \\
\hline Total & 123 & 100.0 \\
\hline
\end{tabular}

Table 2. Distribution of students by graduated high school type

\begin{tabular}{lll}
\hline High School & Frequency & Percent \\
\hline Anadolu High School & 39 & 33.9 \\
General High School & 33 & 28.7 \\
Religious High School & 20 & 17.4 \\
Vocational High School & 10 & 8.7 \\
Others (Industrial Vocational High School, Science High School, & 13 & 11.4 \\
Teacher High School, Technical High School) & & 100.0 \\
\hline Total & 123 & \\
\hline
\end{tabular}

Table 3. Distribution of students by age

\begin{tabular}{lll}
\hline Age & Frequency & Percent \\
\hline Up to19 & 63 & 51.6 \\
20 & 36 & 29.5 \\
21 & 13 & 10.7 \\
Above 22 & 10 & 8.1 \\
\hline Total & 122 & 100.0 \\
\hline
\end{tabular}

Table 4. Distribution of students by types of education

\begin{tabular}{lll}
\hline Types of Education & Frequency & Percent \\
\hline Daytime Education & 66 & 54.1 \\
Evening Education & 56 & 45.9 \\
\hline Total & 122 & 100.0 \\
\hline
\end{tabular}

Table 5. Distribution of students by being a netizen

\begin{tabular}{lll}
\hline I am using internet for about ... & Frequency & Percent \\
\hline 1 year & 5 & 4.3 \\
2 years & 7 & 6 \\
3 years & 4 & 3.4 \\
4 years & 8 & 6.9 \\
5 years & 17 & 14.7 \\
6 years & 9 & 7.8 \\
7 years & 11 & 9.5 \\
8 years & 10 & 8.6 \\
9 years & 11 & 9.5 \\
10 years & 21 & 18.1 \\
11 years or more & 13 & 11.3 \\
\hline Total & 116 & 100.0 \\
\hline
\end{tabular}

Table 6. Distribution of students by "existence of internet connectivity which can be used consistently"

\begin{tabular}{lll}
\hline Response & Frequency & Percent \\
\hline Yes & 66 & 54.1 \\
Partly & 33 & 27 \\
No & 23 & 18.9 \\
\hline Total & 122 & 100.0 \\
\hline
\end{tabular}


Table 7. Distribution of students by attendance of any distance education course before

\begin{tabular}{lll}
\hline Response & Frequency & Percent \\
\hline No & 110 & 90.2 \\
Yes & 12 & 9.8 \\
\hline Total & 122 & 100.0 \\
\hline
\end{tabular}

Table 8. Distribution of students by skills for computer usage

\begin{tabular}{lll}
\hline Response & Frequency & Percent \\
\hline Excellent & 17 & 13.9 \\
Good & 33 & 27 \\
Average & 57 & 46.7 \\
Fair & 13 & 10.7 \\
Poor & 2 & 1.6 \\
\hline Total & 122 & 100.0 \\
\hline
\end{tabular}

Table 9. Distribution of students by ways to reach the course content

\begin{tabular}{lll}
\hline Ways & Frequency & Percent \\
\hline With my personal devices (desktop computer, & & \\
tablet, smartphone etc.) & 90 & 75 \\
With my friends devices & 18 & 15 \\
With school devices located in campus & 6 & 5 \\
With devices of internet cafes & 3 & 2.5 \\
\hline Total & 120 & 100.0 \\
\hline
\end{tabular}

Do the students who attended APHR, TL and BIT distance education courses have any information on distance education?

Table 10. Distribution of students by having any information on distance education

\begin{tabular}{lll}
\hline Response & Frequency & Percent \\
\hline Yes, I have information on distance education. & 78 & 65 \\
I partly have information on distance education. & 30 & 25 \\
No, I have no information on distance education. & 12 & 10 \\
\hline Total & 120 & 100.0 \\
\hline
\end{tabular}

Table 11. Distribution of students by whether they have any problem on reaching system

\begin{tabular}{lll}
\hline Response & Frequency & Percent \\
\hline No & 56 & 46.3 \\
Partly & 38 & 31.4 \\
Yes & 27 & 22.3 \\
\hline Total & 121 & 100.0 \\
\hline
\end{tabular}

Table 12. Distribution of students by who reach the course content via tablet

\begin{tabular}{lll}
\hline Response & Frequency & Percent \\
\hline Yes, I reach the course content via my tablet. & 9 & 7.3 \\
No, I don't reach the course content via my tablet. & 114 & 92.7 \\
\hline Total & 123 & 100.0 \\
\hline
\end{tabular}

Table 13. Distribution of students by who reach the course content via smartphone

\begin{tabular}{lll}
\hline Response & Frequency & Percent \\
\hline Yes, I reach the course content via my smartphone. & 53 & 43.1 \\
No, I don't reach the course content via my smartphone. & 70 & 56.9 \\
\hline Total & 123 & 100.0 \\
\hline
\end{tabular}

Table 14. Distribution of students by who reach the course content via desktop computer

\begin{tabular}{lll}
\hline Response & Frequency & Percent \\
\hline Yes, I reach the course content via my desktop computer. & 22 & 17.8 \\
No, I don't reach the course content via my desktop computer. & 101 & 82.1 \\
\hline Total & 123 & 100.0 \\
\hline
\end{tabular}

Table 15. Distribution of students by who reach the course content via laptop

\begin{tabular}{lll}
\hline Response & Frequency & Percent \\
\hline Yes, I reach the course content via my laptop. & 68 & 55.3 \\
No, I don't reach the course content via my laptop. & 55 & 44.7 \\
\hline Total & 123 & 100.0 \\
\hline
\end{tabular}

What are the students' perceptions about the impact of attending APHR, TL and BIT courses as distance education on 
achieving learning outcomes?

Table 16. Distribution of students' perceptions about the impact of attending APHR, TL and BIT courses as distance education on achieving learning outcome

\begin{tabular}{lllllll}
\hline & \multicolumn{2}{c}{ APHR } & \multicolumn{2}{c}{ TL } & \multicolumn{2}{c}{ BIT } \\
\hline Response & Frequency & Percent & Frequency & Percent & Frequency & Percent \\
\hline It depends on the background & & & & & & \\
and efforts of a student. & 57 & 46.7 & 57 & 46.7 & 54 & 44.3 \\
It is successful. & 47 & 38.5 & 49 & 40.2 & 34 & 27.9 \\
It is not successful. & 18 & 14.8 & 16 & 13.1 & 34 & 27.9 \\
\hline Total & 122 & 100.0 & 122 & 100.0 & 122 & 100.0 \\
\hline
\end{tabular}

What are the perceptions of the students who attended APHR, TL and BIT courses in distance education about the convenience of these courses for distance education?

Table 17. Distribution of students' perceptions about the convenience of teaching APHR, TL and BIT courses as distance education

\begin{tabular}{lllllll}
\hline & \multicolumn{2}{c}{ APHR } & \multicolumn{2}{c}{ TL } & \multicolumn{2}{c}{ BIT } \\
\hline Response & Frequency & Percent & Frequency & Percent & Frequency & Percent \\
\hline Yes & 53 & 43.4 & 67 & 54.9 & 51 & 41.8 \\
No & 51 & 41.8 & 32 & 26.2 & 57 & 46.7 \\
Partly & 12 & 9.8 & 18 & 14.8 & 6 & 4.9 \\
No idea & 6 & 4.9 & 5 & 4.1 & 8 & 6.6 \\
\hline Total & 122 & 100.0 & 122 & 100.0 & 122 & 100.0 \\
\hline
\end{tabular}

What is the students' behavior of spending time with other things during the course who attended APHR, TL and BIT distance education courses?

Table 18. Distribution of students' behavior of spending time with other things during the course who attended APHR, TL and BIT distance education courses?

\begin{tabular}{lllllll}
\hline & \multicolumn{2}{c}{ APHR } & \multicolumn{2}{c}{ TL } & \multicolumn{2}{c}{ BIT } \\
\hline Response & Frequency & Percent & Frequency & Percent & Frequency & Percent \\
\hline Never & 30 & 24.8 & 29 & 24.4 & 27 & 22.7 \\
Seldom & 32 & 26.4 & 31 & 26.1 & 25 & 21 \\
Sometimes & 41 & 33.9 & 41 & 34.5 & 38 & 31.9 \\
Often & 14 & 11.6 & 13 & 10.9 & 19 & 16 \\
Always & 4 & 3.3 & 5 & 4.2 & 10 & 8.4 \\
\hline Total & 122 & 100.0 & 122 & 100.0 & 122 & 100.0 \\
\hline
\end{tabular}

What are the attitude scores of students who attended APHR, TL and BIT distance education courses toward teaching these courses with distance education?

Table 19. Scores toward teaching APHR, TL and BIT with distance education

\begin{tabular}{lllll}
\hline \multicolumn{1}{c}{ Course } & Minimum Score & Maximum Score & Mean & Standart Deviation \\
\hline APHR & 1.57 & 4.81 & 2.92 & 0.62 \\
TL & 1.90 & 4.62 & 2.95 & 0.59 \\
BIT & 1.95 & 4.62 & 2.93 & 0.59 \\
\hline
\end{tabular}

Is there any statistically significant difference by "gender" on attitude scores of students toward teaching APHR, TL and BIT courses with distance education who attend these courses as distance education?

Table 20. Independent samples t-test results for attitude scores of students' toward teaching APHR, TL and BIT courses with distance education based on "gender"

\begin{tabular}{llllllll}
\hline Course & Gender & $\mathrm{n}$ & Mean & Standart Deviation & $\mathrm{t}$ & $\mathrm{df}$ & Sig. \\
\hline APHR & Female & 64 & 2.83 & 0.56 & -1.681 & 121 & 0.095 \\
TL & Male & 59 & 3.01 & 0.67 & -1.767 & 121 & 0.08 \\
\hline BIT & Female & 64 & 2.86 & 0.54 & & & \\
APHR & Male & 59 & 3.04 & 0.62 & -2.200 & 121 & $0.03^{*}$ \\
\hline & Female & 64 & 2.82 & 0.53 & & & \\
TL & Male & 59 & 3.05 & 0.62 & & & \\
\hline
\end{tabular}

There is a statistically significant difference between the attitude level of the male and female students for only BIT course. Furthermore male students have a more positive attitude (3.05 \pm 0.62$)$ than female students $(2.82 \pm 0.53)$ to attending BIT course as distance education.

Are there any statistically significant differences by "existence of internet connectivity which can be used consistently" on attitude scores of students' toward teaching APHR courses with distance education who attend to these courses as distance education? 
Table 21. ANOVA results for attitude scores of students' toward teaching APHR course with distance education based on "existence of internet connectivity which can be used consistently"

\begin{tabular}{llllll}
\hline Source & SS & df & MS & F & Sig. \\
\hline Between & 5.791 & 2 & 2.896 & \multirow{2}{*}{8.382} & $0.000^{*}$ \\
Within & 41.112 & 119 & 0.345 & & \\
\hline Total & 49.903 & 121 & & & \\
\hline
\end{tabular}

There are statistically significant differences found by "existence of internet connectivity which can be used consistently" on attitude scores of students' toward teaching APHR course with distance education who are attending APHR course as distance education.

Table 22. Results of post hoc tests (APHR course)

\begin{tabular}{lllll}
\hline Response & $\mathrm{n}$ & Mean & Standart & Deviation \\
\hline Yes & 66 & 3.1219 & 0.65463 & \\
No & 23 & 2.6542 & 0.50807 & \\
Partly & 33 & 2.7085 & 0.48661 & \\
\hline Total & 122 & 2.9219 & 0.62260 & \\
\hline
\end{tabular}

\begin{tabular}{ll}
\hline Post Hoc Test & Responses \\
\hline Tukey & "Yes"-"No" \\
& "Yes" - "Partly" \\
\hline
\end{tabular}

According to Table 22 the students that have a consistent internet connection (those whose answer is "Yes") have a more positive attitude (3.12 \pm 0.65$)$ than the students that do not have a regular internet connection (those whose answer is "No") (2.65 \pm 0.51$)$ or the students that have a partly consistent internet connection (those whose answer is "Partly") $(2.71 \pm 0.49)$ to APHR as distance education.

Are there any statistically significant differences by "existence of internet connectivity which can be used consistently" on attitude scores of students' toward teaching TL courses with distance education who attend to these courses as distance education?

Table 23. ANOVA results for attitude scores of students' toward teaching TL course with distance education based on "existence of internet connectivity which can be used consistently"

\begin{tabular}{llllll}
\hline Source & SS & df & MS & F & Sig. \\
\hline Between & 3.850 & 2 & 1.925 & 5.999 & $0.003^{*}$ \\
Within & 38.189 & 119 & 0.321 & & \\
\hline Total & 42.039 & 121 & & & \\
\hline
\end{tabular}

There are statistically significant differences found by "existence of internet connectivity which can be used consistently" on attitude scores of students' toward teaching TL course with distance education who are attending TL course as distance education.

Table 24. Results of post hoc tests (TL course)

\begin{tabular}{lllll}
\hline Response & $\mathrm{n}$ & Mean & Standart & Deviation \\
\hline Yes & 66 & 3.1089 & 0.61488 & \\
No & 23 & 2.7598 & 0.52685 & \\
Partly & 33 & 2.7475 & 0.48438 & \\
\hline Total & 122 & 2.9454 & 0.58943 & \\
\hline
\end{tabular}

\begin{tabular}{ll}
\hline Post Hoc Test & Responses \\
\hline Tukey & "Yes"-"No" \\
& "Yes" - "Partly" \\
\hline
\end{tabular}

According to Table 24 the students that have a consistent internet connection (those whose answer is "Yes") have a more positive attitude $(3.11 \pm 0.61)$ than the students that do not have a regular internet connection (those whose answer is "No") $(2.76 \pm 0.53)$ or the students that have a partly consistent internet connection (those whose answer is "Partly") $(2.75 \pm 0.48)$ to attending TL as distance education.

Are there any statistically significant differences by "existence of internet connectivity which can be used consistently" on attitude scores of students' toward teaching BIT courses with distance education who attend to these courses as distance education?

Table 25. ANOVA results for attitude scores of students' toward teaching BIT course with distance education based on "existence of internet connectivity which can be used consistently"

\begin{tabular}{llllll}
\hline Source & SS & df & MS & F & Sig. \\
\hline Between & 3.776 & 2 & 1.888 & 5.900 & $0.004^{*}$ \\
Within & 38.074 & 119 & 0.320 & & \\
\hline Total & 41.850 & 121 & & & \\
\hline
\end{tabular}

There are statistically significant differences found by "existence of internet connectivity which can be used consistently" on attitude scores of students' toward teaching BIT course with distance education who are attending BIT course as distance education. 
Table 26. Results of post hoc tests (BIT course)

\begin{tabular}{lllll}
\hline Response & $\mathrm{n}$ & Mean & Standart & Deviation \\
\hline Yes & 66 & 3.0851 & 0.61639 & \\
No & 23 & 2.7847 & 0.52829 & \\
Partly & 33 & 2.7027 & 0.47560 & \\
\hline Total & 122 & 2.9251 & 0.58811 &
\end{tabular}

\begin{tabular}{ll}
\hline Post Hoc Test & Responses \\
\hline Tukey & "Yes" - "Partly" \\
\hline
\end{tabular}

According to Table 26 the students that have a consistent internet connection (those whose answer is "Yes") have a more positive attitude (3.09 \pm 0.62$)$ than the students that have a partly consistent internet connection (those whose answer is "Partly") (2.70 \pm 0.48$)$ to attending BIT as distance education.

Is there an association between "course type (APHR/TL/BIT)" and "the students' perceptions about the impact of attending these courses as distance education on achieving learning outcomes"?

Table 27. "Course type" - "Achieving learning outcomes"

\begin{tabular}{lllll}
\hline & $\begin{array}{l}\text { It is } \\
\text { successful. }\end{array}$ & It is not successful. & $\begin{array}{l}\text { It depends on the background } \\
\text { and efforts of a student. }\end{array}$ & Total \\
\hline APHR & 47 & 18 & 57 & 122 \\
TL & 49 & 16 & 57 & 122 \\
BIT & 34 & 34 & 34 & 122 \\
\hline Total & 130 & 68 & 168 & 366 \\
\hline
\end{tabular}

There is a statistically significant association between "course type" and "the students' perceptions about the impact of attending these courses as distance education on achieving learning outcomes" $\left(\chi^{2}(4)=11.757, \quad p=0.019\right)$.

Is there an association between "course type (APHR/TL/BIT)" and "students' perceptions about the convenience of teaching these courses as distance education"?

Table 28. "Course type" - "Convenience of teaching these courses as distance education"

\begin{tabular}{llllll}
\hline & Yes & No & Partly & No idea & Total \\
\hline APHR & 53 & 51 & 12 & 6 & 122 \\
TL & 67 & 32 & 18 & 5 & 122 \\
BIT & 51 & 57 & 6 & 8 & 122 \\
\hline Total & 171 & 140 & 36 & 19 & 366
\end{tabular}

There is a statistically significant association between "course type" and "students' perceptions about the convenience of teaching these courses as distance education" $\left(\chi^{2}(6)=16.704, \quad p=0.010\right)$.

Is there an association between "course type (APHR/TL/BIT)" and "students' behavior of spending time with other things during these courses"?

Table 29. "Course type" - "Spending time with other things"

\begin{tabular}{lllllll}
\hline & Never & Seldom & Sometimes & Often & Always & Total \\
\hline APHR & 30 & 32 & 41 & 14 & 4 & 121 \\
TL & 29 & 31 & 41 & 13 & 5 & 119 \\
BIT & 27 & 25 & 38 & 19 & 10 & 119 \\
\hline Total & 86 & 88 & 120 & 46 & 19 & 359 \\
\hline
\end{tabular}

There is no statistically significant association between "course type" and "students' behavior of spending time with other things during these courses" $(\chi 2(8)=5.890, p=0.660$.

\section{Discussion}

The majority of students (90.2\%) did not experience distance education before taking their APHR, TL and BIT courses in distance education, in other words, most of them did not get acquainted with distance education. However, more than half of the students $(65 \%)$ were found to have knowledge of distance education.

Nearly half of the students who answered the questionnaire, indicated that success of taking APHR, TL and BIT courses in distance education in course achievements depended on "student's background knowledge and effort". Nevertheless, in the study of Doğan \& Tatık (2015), it was seen that the perceptions of the students regarding the success of distance education in attaining course achievements were mostly negative.

When the perceptions of the students regarding the convenience of APHR, TL and BIT courses for distance education were examined, it was seen that the highest rate for APHR course was "Yes" (43.4\%), the highest rate for TL course was "Yes" (54.9\%) and the highest rate for BIT course was "No" (46.7\%). However, in the study conducted by Yalman \& Kutluca (2013), it was seen that students who studied mathematics education in the education faculty answered "Partially"(45.10\%) as the highest rate in their answers regarding the convenience of their departmental courses for distance education. 
It was found that $14.9 \%$ (for APHR), 15.1\% (for TL), 24.4\% (for BIT) of the students took an interest in other things on the internet during the APHR, TL and BIT courses respectively with answers "Often" or "Always". Likewise, Türkoğlu (2015) stated in his study, which he conducted with students taking Information and Communication Technologies course in distance education, that $22.5 \%$ of the students initiate distance education system, but take an interest in other things.

For only BIT course there was found statistically significant difference by "gender" on attitude scores of students' toward teaching courses with distance education who are attending these courses as distance education. For other courses (APHR and TL) there was no statistically significant difference found by "gender" on attitude scores of students' toward teaching courses with distance education. At the relevant literature;

- In a study conducted by Kışla (2005) there was no statistically significant difference found by "gender" on attitude scores of students' toward teaching courses with distance education.

- In a study conducted by Barış (2015) there was no statistically significant difference found by "gender" on attitude scores of students' toward teaching courses with distance education who are attending APHR/TL/Foreign Language courses as distance education.

- In a study conducted by Türkoğlu (2015) it was found that female students have more positive regarding levels to the course than male students who are attending Information and Communication Technologies courses as distance education.

Students who have internet connectivity which can be used consistently look at taking APHR, TL and BIT courses in distance education more positively than the students who do not have a internet connectivity which can be used consistently or those who have partial internet connectivity which can be used consistently. Similarly, in the study conducted by Barış (2015), on the students taking APHR/TL/Foreign Language courses in distance education, attitude levels of the students who have internet connectivity which can be used consistently turned out to be higher than the attitude levels of the students who do not have internet connectivity which can be used consistently.

There was found statistically significant association between "course type" and "the students' perceptions about the impact of attending these courses as distance education on achieving learning outcomes. There was also found statistically significant association between "course type" and "students' perceptions about the convenience of teaching these courses as distance education". However, there was no statistically significant association found between "course type (APHR/TL/BIT)" and "students' behavior of spending time with other things during these courses".

Further studies should be conducted to see and eliminate the problems experienced during practice and to get the desired yield from APHR/TL/BIT courses which are offered in distance education.

\section{References}

Barış, M. F. (2015). Analyzing the university students' attitudes towars distance education: Namık Kemal University case study. Sakarya University Journal of Education, 5(2), 36-36. https://doi.org/10.19126/suje.38758

Büyüköztürk, Ş., Kılıç, Ç. E., Akgün, Ö., Karadeniz, Ş., \& Demirel, F. (2010). Scientific research methods. Ankara: Pegem Akademi.

Demiray, U. (1994). A review of the literature on the open education faculty. Eskişehir: Anadolu University Publications.

Doğan, S., \& Tatık, R. Ş. (2015). Evaluation of distance education program in Marmara University according to the views of students. Route Educational and Social Science Journal, 2(1), 247-261. https://doi.org/10.17121/ressjournal.187

Eygü, H., \& Karaman, S. (2013). A study on the satisfaction perceptions of the distance education students. Klrlkkale University Journal of social Sciences, 3(1), 36-59.

İşman, A. (2011). Distance education. Ankara: Pegem Akademi.

Karasar, N. (2012). Scientific research method. Ankara: Nobel Yayınları

Kaya, Z. (2002). Distance education. Ankara: PegemA Yayınc1lı.

Keegan, D. (1990). Foundations of distance education (2nd ed.). London: Routledge.

Kışla, T. (2005). Üniversite öğrencilerinin uzaktan eğitime yönelik tutumları [University students' attitudes about distance education]. Unpublished master's thesis, Ege University, İzmir.

Moore, M., \& Kearsley, G. (2012). Distance education: A systems view of online learning (3rd ed.). Belmond, CA: Wadsworth Cengage Learning. 
Özdil, İ. (1986). International framework of distance education and the place of distance education in Turkish educational system. Eskişehir: Anadolu University Publications.

Öztaş, S., \& Kılıç, B. (2017). The evaluation of university students' opinions of teaching the Atatürk's principles and history of revolution cource with distance education (Kırklareli University sample). Turkish History Education Journal, 6(2), 268-293.

Parlak, Ö. (2007). Student satisfaction scale on internet based distance education. Educational Sciences \& Pactise, 6(11), 53-72.

Schosser, L. A., \& Simonson, M. (2009). Distance education: Definition and glossary of terms (3rd ed.). Charlotte, NC: Information Age.

Türkoğlu, T. (2015). The attitudes of students at vocational schools formal education program on distance education cource. Electronic Journal of Vocational Colleges, 4th UMYOS Special Issue, 31-38.

Verduin, J. R., \& Clark, J. T. (1994). Distance education: Effective implementation principles. Translated: İlknur Maviş. Eskişehir: Anadolu University Publications.

Yalman, M., \& Kutluca, T. (2013). Mathematics prospective teachers' approaches towards the distance education system used for the department cources. Dicle University Journal of Ziya Gokalp Education Faculty, 21, 197-208.

\section{Copyrights}

Copyright for this article is retained by the author(s), with first publication rights granted to the journal.

This is an open-access article distributed under the terms and conditions of the Creative Commons Attribution license which permits unrestricted use, distribution, and reproduction in any medium, provided the original work is properly cited. 